\title{
Potential Anti-wrinkle Activity of Chlorella sp. HS1-derived Oil Components on Human Dermal Fibroblasts
}

\author{
Hye-Bin Kim ${ }^{1}$, Ji Yea Kim¹, Sungkwan An ${ }^{1}$, Yong Jae Lee ${ }^{2}$, Dae-Hyun $\mathrm{Cho}^{2}$, Hee-Sik Kim ${ }^{2,3}$, Seunghee Bae ${ }^{1 \star}$ \\ ${ }^{1}$ Research Institute for Molecular-Targeted Drugs, Department of Cosmetics Engineering, Konkuk University, Seoul, Korea \\ ${ }^{2}$ Sustainable Bioresource Research Center, KRIBB, Daejeon, Korea \\ ${ }^{3}$ Green Chemistry and Environmental Biotechnology, University of Science and Technology (UST), Daejeon, Korea
}

\author{
*Corresponding author: Seunghee \\ Bae, Research Institute for Molecular- \\ Targeted Drugs, Department of Cosmetics \\ Engineering, Konkuk University, 120 \\ Neungdong-ro, Gwangjin-gu, Seoul 05029, \\ Korea \\ Tel.: +82 24500463 \\ Email: sbae@konkuk.ac.kr
}

Received December 24, 2019

Revised March 05, 2020

Accepted March 09, 2020

Published March 30, 2020

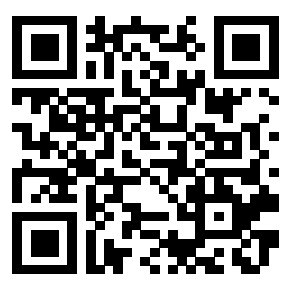

\begin{abstract}
Purpose: In this study, we investigated the effects of Chlorella sp. HS1-derived oils on collagen expressions in dermal fibroblasts. Methods: We prepared the oil extracts from Chlorella sp. HS1 biomass, and high-performance liquid chromatography analysis was used in the identification and quantitation of components in the oil extracts. Using human dermal fibroblasts, cell viability and quantitative RT-PCR (qRTPCR)-mediated expression analysis of collagen and matrix metalloprotease (MMP) genes after oil treatments. We further investigated whether the effect of the oil extracts on collagen expression was related to the major component, $\beta$-carotene, of the extracts. In addition, we analyzed the effect of photoprotective effect of $\beta$-carotene on ultraviolet (UV)-irradiated dermal fibroblasts. Results: We found that under $50 \mu \mathrm{g} / \mathrm{mL}$ of the oil extracts had little cytotoxicity in skin cells including epidermal keratinocytes, melanocytes and dermal fibroblasts. The HPLC analysis revealed that $\beta$-carotene was identified as the major non-polar molecules. Next, we found that the oil-derived $\beta$-carotene was little cytotoxicity in dermal fibroblasts. Further experiments revealed that treatment with the oil extracts significantly upregulated collagen type 1 and 3 mRNAs and downregulated MMP1 and MMP3 mRNAs in dermal fibroblasts. Also, we found that these effects were showed in $\beta$-carotene-treated cells. In addition, $\beta$-carotene significantly attenuated UVA-induced downregulation of collagen type 1 and 3 expressions. Conclusion: Therefore, our results suggested that the oil extracts had a potential anti-wrinkle agent via its major component, $\beta$-carotene.
\end{abstract}

Keywords: Chlorella sp., Dermal fibroblasts, Anti-aging, Collagen, $\beta$-carotene

\section{Introduction}

피부는 외부 환경으로부터 신체를 구별하는 장벽으로, 수분 손실 과 미생물에 대한 감염으로부터 신체를 보호할 뿐만 아니라, 화장품 적인 역할에도 중요하게 작용한다(Zhang \& Duan, 2018). 특히, 젊 고 아름다운 외모는 사람들간의 사회적 행동에 긍정적인 영향을 준 다고 보고되고 있다(Blanpain \& Fuchs, 2006). 신체의 모든 기관은 태어난 이후 노화 과정이 시작되며, 피부의 경우도 예외는 아니다 (Zhang \& Duan, 2018). 신체의 기관 중 가장 큰 부분을 차지하는 피부는 나이가 들어감에 따라 가장 분명하고 가시적인 노화의 정도 를 보여준다(Zhang \& Duan, 2018). 따라서, 특히 대다수의 사람은
피부 노화 개선 및 방지를 위해 화장품 또는 의약품에 상당수의 비 용을 지출하고 있다. 이러한 방대한 화장품적 요구는 피부 노화 및 관련 치료에 대한 연구를 지속적으로 촉진하고 있다(Kazanci et al., 2016).

피부 노화는 내인적(intrinsic) 요소와 외인적(extrinsic) 요소에 의하여 유도된다. 내인성 노화는 피할 수 없는 생리학적 과정으로 피부 두께 감소, 건조, 잔주름(fine wrinkles), 지속적 진피 위축 등 의 결과를 가져오며, 외인성 노화는 공기오염, 흡연, 영양 부족, 자 외선 노출 등의 외부 환경적 요인들에 의하여 발생되며, 깊은 주름, 피부 탄력 감소, 피부 처짐(laxity), 거친 피부결 등의 결과를 가져 온다(Krutmann et al., 2017; Mora et al., 2016). 특히, 자외선 
(ultraviolet, UV)에 대한 장기간의 노출은 외인성 피부노화의 가장 주요한 요인으로 작용하고 있어 광노화(photoaging)이라고도 일컫 는다(Mora et al., 2016).

노화된 피부에서 가장 대표적으로 나타나는 변화는 콜라겐 (collagen) 섬유의 양적 및 구조학적 변화이다(Fisher et al., 1997; Quan \& Fisher, 2015) 젊은 피부에서 콜라겐 섬유는 상대적으로 풍부하며, 잘 정리된 구조를 보이는 반면, 노화된 피부에서의 콜라 겐 섬유는 분해가 되어 흩어져 있는 변화를 가진다(Quan \& Fisher, 2015; Yasui et al., 2013). 기존 연구들을 통해 콜라겐 분해의 증 가와 콜라겐 생합성의 감소가 동시에 콜라겐 항상성의 이상을 초래 하며, 이는 전체적인 콜라겐 감소증을 유발한다고 보고하고 있다 (Fisher et al., 1997; Fisher et al., 2008). 이러한 변화는 임상학 적으로 노화된 피부에서 나타나는 주름 발생 및 탄력 감소를 초래한 다(Fisher et al., 1997; Varani et al., 2000).

Matrix metalloproteinase (MMP) 효소는 세포외기질 (extracellular matrix, ECM) 단백질을 분해할 수 있는 기능을 가 지며, 세부적으로 collagenases, gelantinases, stromelysins, matrilysins, membrane-type MMPs로 나뉠 수 있다(Pittayapruek et al., 2016). 특히, MMP-1은 콜라겐 섬유의 분해를 유발하는 주 요한 효소로 인간 피부에 존재하는 콜라겐 타입 I과 III의 분해에 주 로 관여한다(Brennan et al., 2003). 인간 피부에 있어, MMPs의 주 요한 생합성 은 진피층(dermis layer)에 존재하는 인간 진피섬유아 세포(human dermal fibroblasts)가 담당하고 있다(Brennan et al., 2003). 기존 연구 논문에 의하면 노화된 인간 피부에서 $M M P-1$ 및 $M M P-3$ 의 수준이 현저히 증가되어 있음을 나타내, 피부노화 억 제에 있어 $M M P-1$ 및 $M M P-3$ 의 발현 감소의 중요함을 시사한다 (Quan et al., 2013).

Chlorella는 1980년 발굴된 단세포 미세조류의 한 종류로 단백 질, 핵산, 탄수화물, 클로로필, 비타민, 미네랄 등 다양한 영양 물질 들이 함유되어 있어, 의약학적 산업에 잠재적인 적용에 대해서 많 은 연구가 진행되고 있다(Krienitz et al., 2015). 또한, Chlorella는 베타카로틴( $\beta$-carotene), 루테인(lutein), 클로로필II-a, 아스코빅 산(ascorbic acid), 토코페롤(tocopherol), 레티놀(retinol)을 함유하 고 있다(Kitada et al., 2009; Panahi et al., 2012). 다양한 연구를 통해 Chlorella의 이로운 효과에 대해서 보고되고 있으며, 지질 강 화 효과(hypolipidemic action), 당뇨 및 암 억제 효과 등이 그 예이 다(Lee et al., 2008; Vecina et al., 2014; Sulaiman et al., 2006). 뿐만 아니라, 추가적인 연구를 통해 Chlorella의 면역 자극 효과, 콜 라겐 합성 증가, 세포 사멸(apoptosis) 억제 등의 효과가 보고 되었 다(Hasegawa et al., 2000; Makpol et al., 2009). 특히, Chlorella 는 효과적인 항산화력을 가지고 있어, 이러한 효과를 통해 항암 및 항동맥경화(anti-atherogenic property) 효과를 증진 시킬 수 있다 고 보고되었다(Jiang et al., 2010; Wang et al., 2010). 본 연구 그 룹도 Chlorella vulgaris 추출물의 자외선 의존적 인간 진피섬유아세
포의 손상 보호 효능에 대해서 보고하였다(Kim et al., 2014). 하지 만, Chlorella의 오일 추출물에 대한 피부세포 손상 보호 효능 및 관 련 유효 성분에 대해서는 아직 보고되지 않았다. 본 논문은, 미세조 류인 Chlorella sp. HS1의 오일 추출물이 피부노화 억제 효능을 발 휘 할 수 있음을 실험적으로 증명하였다.

\section{Materials and Methods}

\section{1. 시약 및 재료}

Chlorella sp. HS1유래 오일은 한국생명공학연구원(김희식 박 사)을 통해 얻었으며, 본 추출물은 dimethyl sulfoxide (DMSO; Sigma-Aldrich, USA)에 $100 \mathrm{mg}$ (per mL)의 농도로 용해하 여 $-20^{\circ} \mathrm{C}$ 에 보관하였고, 양성 대조군은 transforming growth factor-beta (TGF-beta; Sigma-Aldrich) $5 \mathrm{ng}$ (per mL)로 $-80^{\circ} \mathrm{C}$ 에 보관하였다. 베타-카로틴( $\beta$-carotene; Sigma-Aldrich) 은 tetrahydrofuran (THF; Tokyo Chemical Industry, Japan)과 ethanol (Merckmillipore, Germany) 7:3을 $10 \mathrm{mM}$ 농도로 용해 하여 $-80^{\circ} \mathrm{C}$ 에 보관하였고, 양성 대조군은 아데노신(Adenosine; Sigma-Aldrich) $10 \mathrm{mM}$ 로 $-20^{\circ} \mathrm{C}$ 에 보관하였다.

\section{2. 인간진피섬유아세포 배양}

인간진피섬유아세포(normal human dermal fibroblasts, NHDFs)는 Lonza (Basel, Switzerland)사에서 구입하였으며, Dulbecco's modified eagle medium (DMEM; Biowest, France)에 $10 \%$ fetal bovine serum (FBS; Biowest, France)이 포함된 배지를 사용하여 $37^{\circ} \mathrm{C}, 5 \% \mathrm{CO}_{2}$ 세포배양기를 이용해 배양 및 유지하였다.

\section{3. 세포 생존율 측정}

미세조류오일과 베타-카로틴의 세포 독성은 water-soluble tetrazolium salt (WST-1) assay (EZ-cytox cell viability kit; Itshio, Korea) 법을 통해 측정하였다. 진피섬유아세포를 96-well plate에 $3 \times 10^{3}$ cells (per well)씩 분주하여 세포배양기에 $24 \mathrm{~h}$ 배양 후, 미세조류 오일 $0,1,5,10,20,50,100 \mu \mathrm{g}$ (per $\mathrm{mL}$ )의 농도로 처리하였고, 베타-카로틴은 $0,0.1,0.2,0.5,1,2,5,10,20 \mu \mathrm{M}$ 의 농도로 처리하여 세포배양기에 $24 \mathrm{~h}$ 배양하였다. 배양된 세포 에 EZ-Cytox Cell Viability Assay Kit reagent (iTSBiO, Korea)을 $30 \mathrm{~min}$ 간 처리한 후, iMark Microplate Reader (\#1681130; BioRed, USA)를 이용하여 $450 \mathrm{~nm}$ 의 파장에서 흡광도를 측정하였고, Reference 흡광도는 $650 \mathrm{~nm}$ 의 파장에서 측정한 뒤 결과 값을 결정 하였다.

\section{4. 자외선 조사}

60-mm dish에 있는 media를 제거한 후, phosphate buffered 
saline (PBS; Biowest, France)로 세척하고, 다시 PBS $1 \mathrm{~mL}$ 을 넣어Ultraviolet Illuminator (UV-1000; BoTeck, Korea)에 Ultraviolet B (UVB) $10 \mathrm{~mJ}\left(\right.$ per $\left.\mathrm{cm}^{2}\right)$ 를 조사하였다.

\section{RNA Preperation \& cDNA synthesis}

배양을 통해 얻은 세포를 RiboExTM Total RNA Isolation Solution (GeneAll Biotechnology, Korea)을 각 dish에 처리하 고, Scraper를 이용하여 세포를 용해한 후, 클로로포름(SigmaAldrich)을 넣어 원심 분리 $\left(12000 \mathrm{rpm}, 4^{\circ} \mathrm{C}\right)$ 한다. RNA가 있는 상 층액에 아이소프판올(Merckmillipore, Germany)을 상층액 양만큼 동일하게 넣어 원심 분리 $\left(12000 \mathrm{rpm}, 4^{\circ} \mathrm{C}\right)$ 한 후, $\mathrm{RNA}$ 를 침전시 켜 침전물을 제외한 상층액은 버린다. 남아있는 침전물에 ethanol (Merckmillipore, Germany) 75\% 넣어 원심 분리(12000 rpm, $4^{\circ} \mathrm{C}$ )하여 세척 후, Ethanol을 제거하고, Nuclease-Free Water (Affymetrix, USA)로 용해하여 MaestroNano ${ }^{\circledR}$ Micorovolume Spectrophotometer (MN-913; Maestrogen, USA) A260/A280 파장에서 RNA의 순도와 농도를 측정하였다.

cDNA는 PCR tube에 RNA, DW, Oligo dT (Bionics, Korea), dNTP mixture (Takara, Korea)를 Thermal cycler에 $65^{\circ} \mathrm{C}, 5 \mathrm{~min}$ 돌린 후 $5 \times$ First Strand Buffer (Invitrogen, USA), 0.1M DTT (Invitrogen), M-MLV Reverse Transcriptase (Invitrogen, USA) 넣어 Thermal cycler에 $37^{\circ} \mathrm{C}, 50 \mathrm{~min}, 70^{\circ} \mathrm{C} 15 \mathrm{~min}$ 설정하여 반 응시켰다.

\section{Quantitative real-time polymerase chain reaction (qRT- PCR)}

미세조류 오일과 베타-카로틴에 의한 인간진피섬유아세포 내 에 일어난 유전자 발현을 분석하기 위해 $\mathrm{qRT}-\mathrm{PCR}$ 을 이용하여 분 석하였다. 실험에 사용된 Primer 정보는 다음과 같다(Table 1). 합 성된 cDNA는 해당 유전자의 Primer와 SYBR Green PCR Master Mix (Thermofisher Scientific, USA)를 혼합하고, StepOnePlus
Real-Time PCR System (4379216; Thermo fisher Scientific) 기기를 이용하여 $\mathrm{qRT}-\mathrm{PCR}$ 을 수행하였다. $\mathrm{qRT}-\mathrm{PCR}$ 반응 조 건은 Holding stage에서 $95^{\circ} \mathrm{C}$ 에서 $15 \mathrm{~min}$ 동안 denaturation 후, PCR stage에서 $95^{\circ} \mathrm{C}$ 에서 $30 \mathrm{~s}$ denaturation, $60^{\circ} \mathrm{C}$ 에서 $30 \mathrm{~s}$ annealing, $75^{\circ} \mathrm{C}$ 에서 $30 \mathrm{~s}$ elongation 과정을 45 cycle 반복하여 형광도를 측정하고, 분석하였다. PCR의 유효성을 melting curve로 검증하였고, 각 유전자 발현은 $\mathrm{GAPDH}$ 를 이용하여 normalize 하였 으며, CT값을 이용하여 $2^{-\triangle \triangle C T}$ 방법으로 발현양을 분석하였다.

\section{7. 통계분석 방법}

본 연구의 결과값은 세 번의 독립적인 반복 실험을 실시하여 평 균 \pm 표준편차로 나타냈다. 각 실험에 관하여 Student's $t$-test 방법을 이용하여 검증하였고 유의수준을 0.05 ( $\left.{ }^{*} p<0.05\right), 0.01$ $\left.\left({ }^{* *} p<0.01\right), 0.001{ }^{* * *} p<0.001\right)$ 이하일 경우 통계적으로 유의하다 고 검정하였다.

\section{Results and Discussion}

\section{Chlorella sp. HS1 유래 오일 추출물의 세포독성(cytotoxicity) 평가}

Chlorella sp. HS1 유래 오일 추출물에 대한 진피섬유아세포 내 콜라겐 발현력 변화를 판단하기에 앞서, 해당 추출물을 세포에 처 리하여 나타나는 세포 독성 정도 및 독성 유발 농도를 확인하였다. 피부를 이루는 3 가지 세포를 대상으로 해당 오일을 0-100 $\mu \mathrm{g} / \mathrm{mL}$ 의 농도로 $24 \mathrm{~h}$ 처리한 후, WST-1 assay을 통하여 cell viability 를 분석하여 세포독성을 확인하였다. Figure $1 \mathrm{~A}$ 와 같이, 각질세포 (epidermal keratinocyte)에 오일 추출물을 처리한 결과, $50 \mu \mathrm{g} /$ $\mathrm{mL}$ 의 처리농도 미만에서 세포독성이 나타나지 않았다. 멜라닌 형 성세포(epidermal melanocytes)을 대상으로 평가한 결과 각질세포 에서 나타난 독성결과와 동일하게 $50 \mu \mathrm{g} / \mathrm{mL}$ 의 처리농도 미만에서

Table 1. List of used primers

\begin{tabular}{lll}
\hline Gene & Primer & \multicolumn{1}{c}{ Sequence $\left(5^{\prime} \rightarrow 3^{\prime}\right)$} \\
COL1A1 & Forward & AGGGCCAAGACGAAGACATC \\
& Reverse & AGATCACGTCATCGCACAACA \\
COL3A1 & Forward & GTTTTGCCCCGTATTATGGA \\
& Reverse & GGAAGTCAGGATTGCCGTA \\
MMP1 & Forward & TCTGACGTTGATCCCAGAGAGCAG \\
& Reverse & CAGGGTGACACCAGTGACTGCAC \\
MMP3 & Forward & AGCAAGGACCTCGTTTTCATT \\
& Reverse & GTCAATCCCTGGAAATCTTCA \\
FAPDH & Forward & CGGAGTCAACGGATTTGGTCG TAT \\
& Reverse & AGCCTTCTCCATGGTGGTGAAGAC
\end{tabular}


A

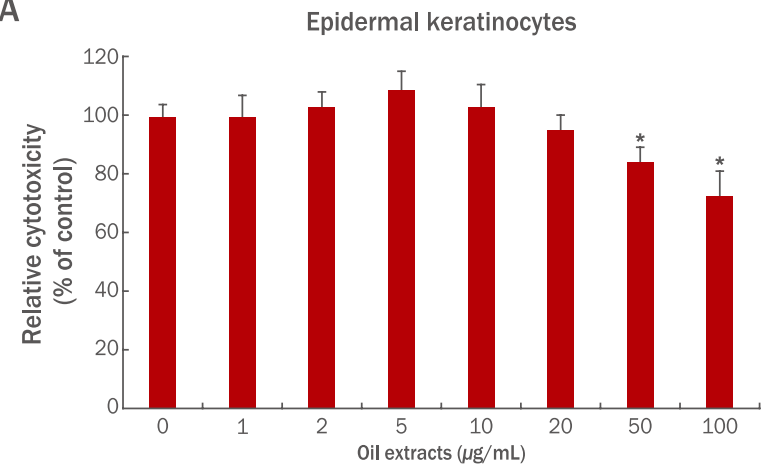

C

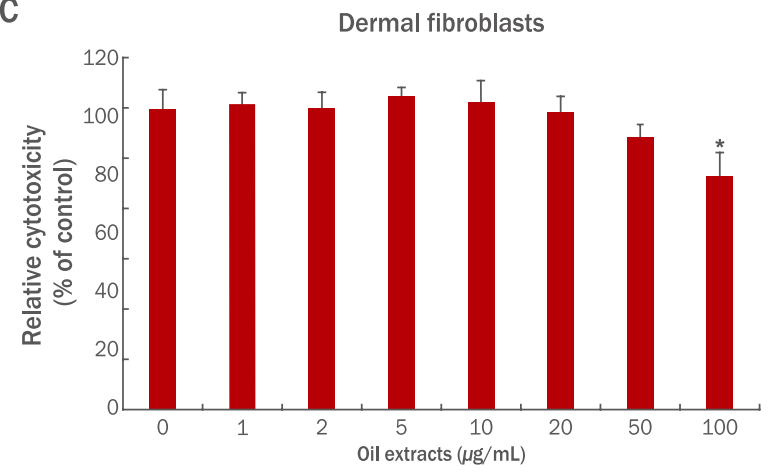

B

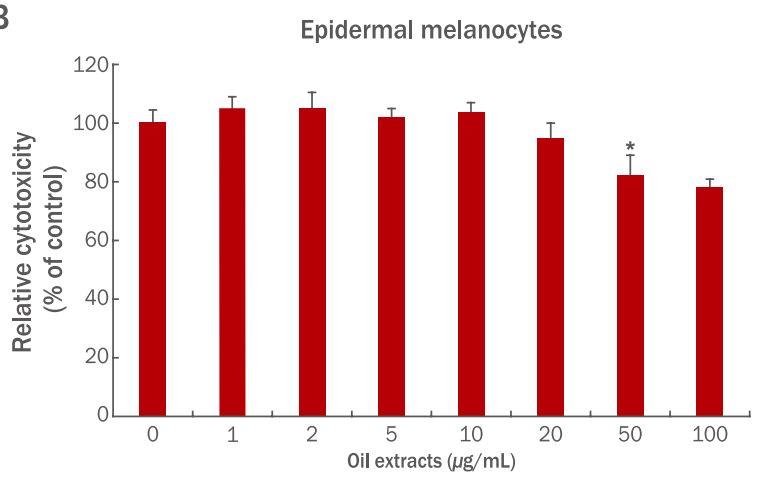

Figure 1. The cell viability analysis of the Chlorella sp. HS1derived oil extracts on human skin cells.

Epidermal keratinocytes, melanocytes and dermal fibroblasts were seeded in 96-well plate and treated with indicated doses of the oil extracts for $24 \mathrm{~h}$. A WST-1 assay was conducted to evaluate the cytotoxicity. Each bar shows mean \pm S.D. from three independent experiments. ${ }^{*} p<0.05$ compared with control.

A

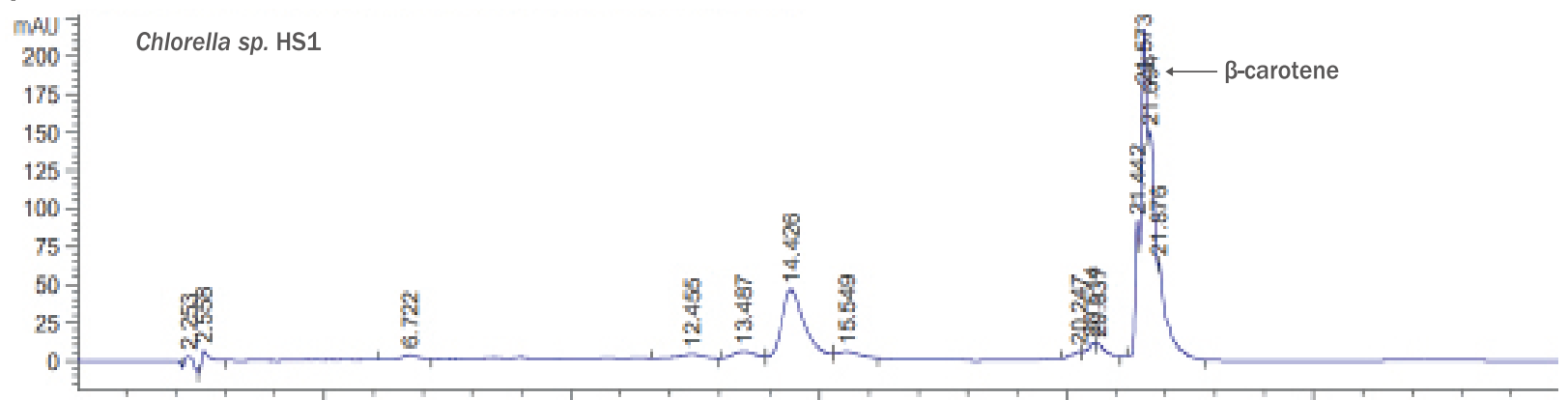

B

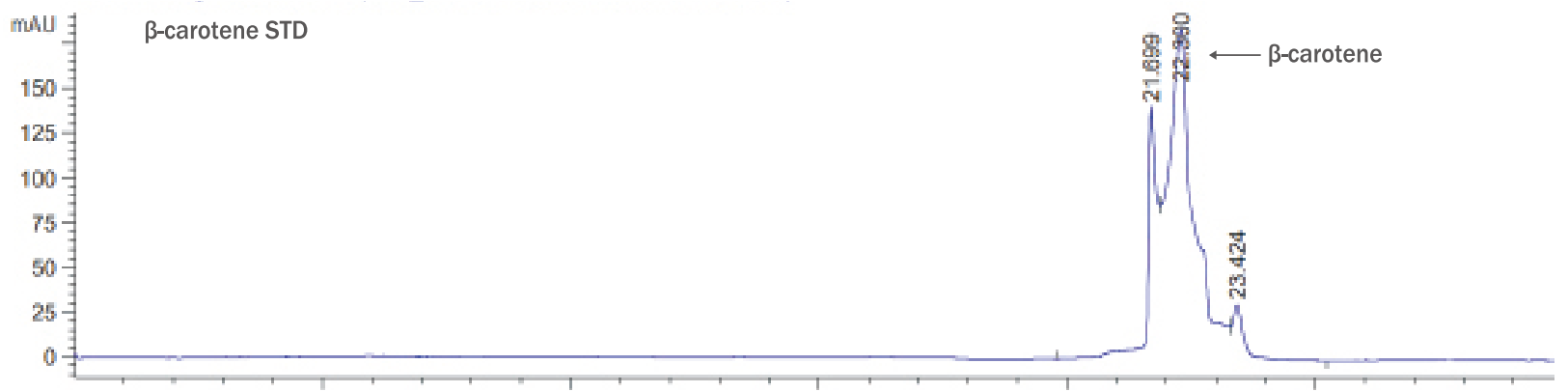

Figure 2. HPLC analysis of Chlorella sp. HS1-derived oil extracts.

(A) HPLC chromatograms of Chlorella sp. HS1-derived oil extracts ; (B) $\beta$-carotene standard. The indicated peak of the oil extracts of Chlorella sp. HS1 was presented at the same retention time as that of the $\beta$-carotene standard. 


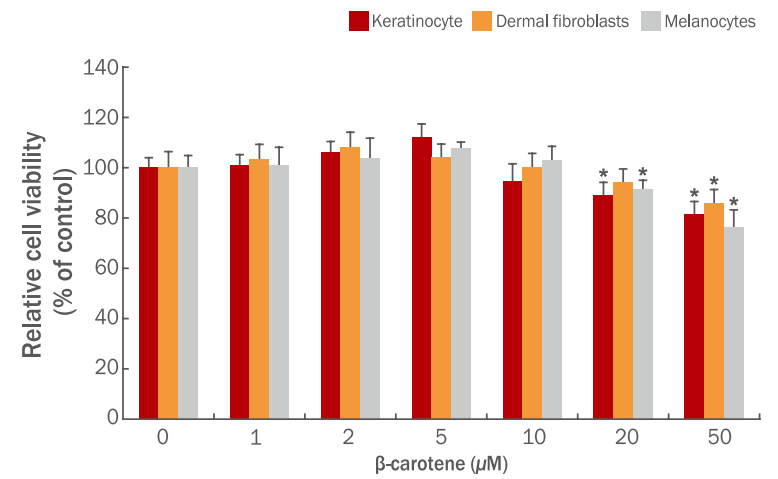

Figure 3. The cell viability analysis of $\beta$-carotene on human skin cells. Epidermal keratinocytes, melanocytes and dermal fibroblasts were seeded in 96-well plate and treated with indicated doses of $\beta$-carotene for $24 \mathrm{~h}$. A WST-1 assay was conducted to evaluate the cytotoxicity. Each bar shows mean \pm S.D. from three independent experiments. ${ }^{*} p<0.05$ compared with control.

세포독성이 나타나지 않았다(Figure 1B). 진피섬유아세포(dermal fibroblasts)에 오일 추출물을 처리한 결과 $100 \mu \mathrm{g} / \mathrm{mL}$ 의 처리농도 미만에서 세포독성이 나타나지 않았다(Figure 1C). 본 실험 결과를 바탕으로 추후 세포 처리농도는 $50 \mu \mathrm{g} / \mathrm{mL}$ 미만으로 하여, 추가적 인 실험을 진행하였다.

\section{Chlorella sp. HS1 유래 오일 추출물의 내 지표성분 탐색}

오일 추출물을 구성하는 여러 성분들을 분석하고, 지표 및 유효 성분을 찾고자, HPLC 실험방법을 통해 오일 추출물의 성분을 분 석하였다. Figure $2 \mathrm{~A}$ 와 같이 $\mathrm{HPLC}$ 를 통하여 분석한 결과 오일 추출물 내 주요한 peak가 2개 탐색되어 있으며, Figure $2 \mathrm{~B}$ 와 같 이 주요한 peak는 $\beta$-carotene의 peak와 동일함을 나타냈다. 따 라서, Chlorella sp. HS1 유래 오일 추출물 내 주요 성분으로는 $\beta$-carotene이 존재함을 밝혀냈다. 이후, Chlorella $s p$. HS1 오 일 유래 $\beta$-carotene의 피부세포 내 효능을 평가하기에 앞서, 3 종류의 피부세포(epidermal keratinocytes, dermal fibroblasts, melanocytes)에 $\beta$-carotene을 0-50 $\mu \mathrm{M}$ 의 농도로 $24 \mathrm{~h}$ 처리 한 후, 세포독성을 확인하였다(Figure 3). 세종류의 피부세포 모두 $\beta$-carotene의 $10 \mu \mathrm{M}$ 이하의 처리농도에서 낮은 세포독성이 보였 다. 본 결과를 바탕으로 추후 $\beta$-carotene의 세포 효능 평가에 있어 서 $10 \mu \mathrm{M}$ 이하의 처리농도를 사용하여 실험하였다.

\section{Chlorella sp. HS1 유래 오일 추출물 및 $\beta$-carotene 의 세포 항노화 평가}

오일 추출물의 피부세포 항노화 기능에 대한 가능성을 평가하 기 위해, 진피 내 콜라겐 생성을 담당하는 진피섬유아세포에 오일

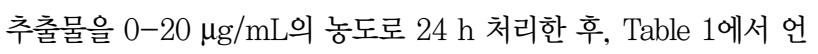
급한 primer를 사용하여 $\mathrm{qRT}-\mathrm{PCR}$ 분석법을 통해 콜라겐 유전자
(COL1A1, COL3A1)의 발현 증감유무를 판단하였다. Figure 4A 와 같이 오일 추출물을 처리하였을때 콜라겐 유전자의 발현이 대조 준 대비 $10 \%$ 이상 증가됨을 확인하였다. 특히, $10 \mu \mathrm{g} / \mathrm{mL}$ 오일 추 출물 처리시 COL1A1 mRNA 발현은 대조군 대비 $10.35 \pm 3.43 \%$ 증가함을 확인하였으나, COL3A1 mRNA의 발현은 오일 추출물 처 리에 따라 통계학적으로 유의한 증가는 나타나지 않았다. 추가적으 로, 오일 추출물 처리에 따라 콜라게나제( $M M P 1, M M P 3)$ 의 발현 증감 유무를 분석하였다. Figure $4 \mathrm{~B}$ 와 같이 오일 추출물을 처리하 였을때 콜라게나제의 발현이 대조군 대비 현저하게 감소됨을 나타 냈다. 특히, $10 \mu \mathrm{g} / \mathrm{mL}$ 오일 추출물 처리시 $M M P 1 \mathrm{mRNA}$ 발현은 대조군 대비 $26.87 \pm 2.95 \%$ 감소함을 확인하였으며 $M M P 3 \mathrm{mRNA}$ 의 발현은 대조군 대비 $21.66 \pm 4.83 \%$ 감소함을 확인하였다. 따라 서, 본 결과를 바탕으로 Chlorella sp. HS1 유래 오일 추출물은 진 피섬유아세포 내 콜라겐 발현을 증가시키고 콜라게나제 발현을 감 소시켜 피부 항노화 소재로서의 가능성을 제시하였다.

상기결과를 바탕으로 오일 추출물에 의한 피부세포 항노화 효과 가 오일 추출물 내 주요 성분인 $\beta$-carotene에 의해서 나타나는지 확인하였다. 진피섬유아세포에 $\beta$-carotene을 0-5 $\mu \mathrm{M}$ 농도로 24 $\mathrm{h}$ 처리한 후, 콜라겐 및 콜라겐나제 발현량을 $\mathrm{qRT}-\mathrm{PCR}$ 을 통해 분 석하였다. 분석결과, $\beta$-carotene 처리 농도 의존적으로 $C O L 1 A 1$ 및 COLSA1 mRNAs의 발현을 현저히 증가시키는 것으로 나타났 으며, $5 \mu \mathrm{M}$ 의 $\beta$-carotene 처리시 대조군 대비 COL1A1 mRNA 의 발현은 대조군 대비 $65.13 \pm 2.45 \%$ 증가하였으며, COL3A1 $\mathrm{mRNA}$ 의 발현은 대조군 대비 $48.13 \pm 3.52 \%$ 증가함을 나타냈다. 뿐만 아니라, $\beta$-carotene 처리 농도 의존적으로 MMP1 및 MMP3 $\mathrm{mRNAs}$ 의 발현을 현저히 감소시키는 것으로 나타났으며, $5 \mu \mathrm{M}$ 의 $\beta$-carotene 처리시 대조군 대비 $M M P 1 \mathrm{mRNA}$ 의 발현은 대조군 대비 $35.76 \pm 3.42 \%$ 감소하였으며, $M M P 3 \mathrm{mRNA}$ 의 발현은 대조 군 대비 $31.66 \pm 2.36 \%$ 감소함을 나타냈다. 따라서, 본 연구결과를 바탕으로 Chlorella $s p$. HS1 유래 오일 추출물에 의해 나타나는 피 부세포 항노화 효과는 $\beta$-carotene에 의한 효과로 나타날 수 있음 을 제시하였다.

\section{4. $\beta$-carotene 의 자외선에 의한 콜라겐 발현 감소 억제력 평가}

피부의 외인성 노화의 주요한 원인 물질로는 자외선이 존재하며, 지속적인 UVA의 노출은 피부 진피층에 존재하는 진피섬유아세포 의 콜라겐 발현량 감소 및 콜라게나제 발현 증가를 유도하여 세포 외기질을 분해한다(Pittayapruek et al., 2016). 따라서, 본 연구 에서는 추가적으로 진피섬유아세포 내 UVA를 조사하여 콜라겐 발 현 감소를 유도한 후, $\beta$-carotene처리 유무에 따라 자외선에 의한 콜라겐 감소 억제능이 존재하는지 평가하였다. 진피섬유아세포에 5-10 $\mu \mathrm{M}$ 의 $\beta$-carotene을 $6 \mathrm{~h}$ 전처리 한 후, $10 \mathrm{~J} / \mathrm{cm}^{2} \mathrm{UVA}$ 를 세 포에 조사하였으며, 이후 다시 5-10 $\mu \mathrm{M}$ 의 $\beta$-carotene을 $24 \mathrm{~h}$ 후 처리 하여, COL1A1 및 COL3A1 mRNA의 발현량을 $\mathrm{qRT}-\mathrm{PCR}$ 법 

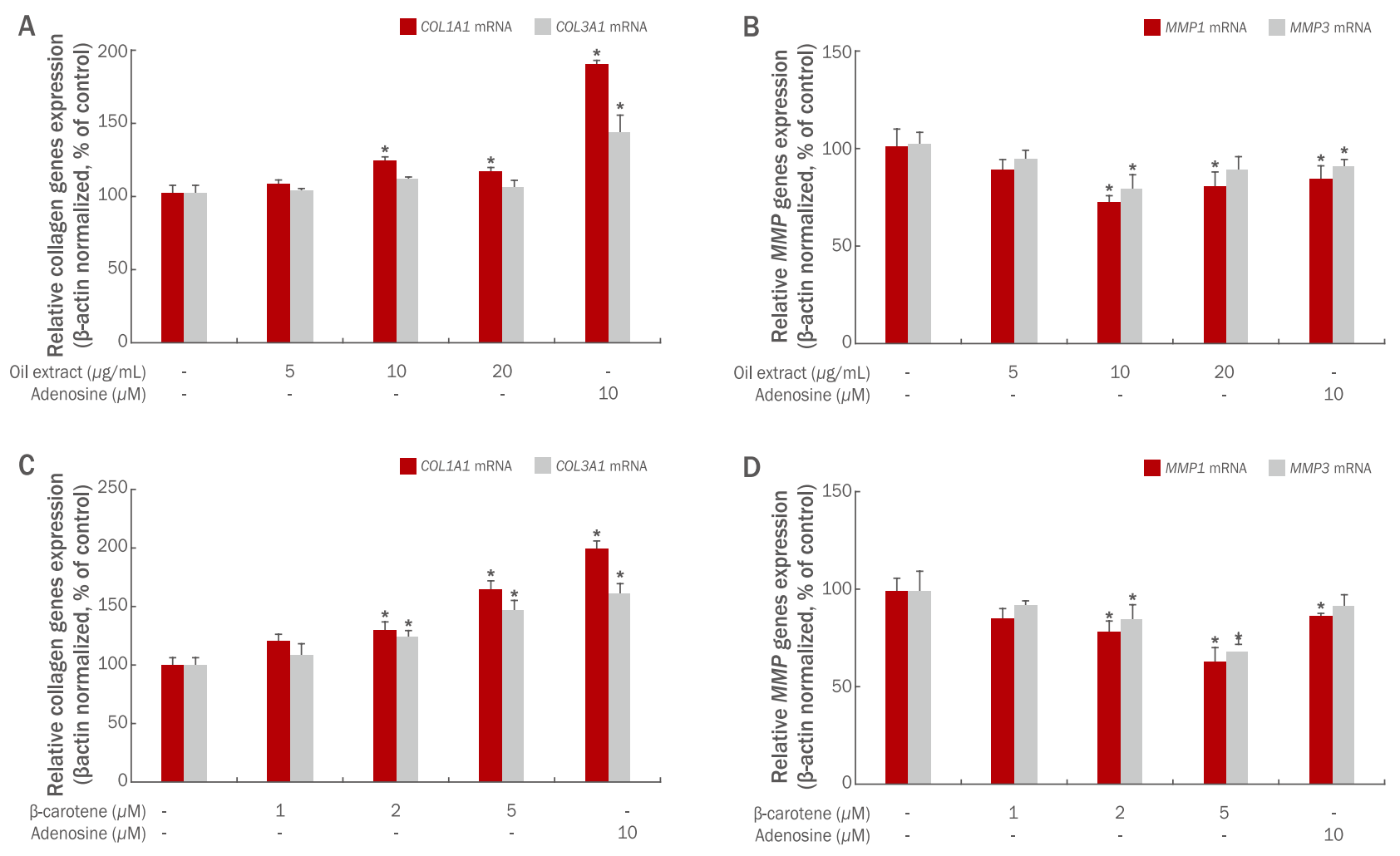

Figure 4. Effect of Chlorella sp. HS1-derived oil extracts and $\beta$-carotene on the expression of type 1 and type 3 collagens, MMP1 and MMP3 in human dermal fibroblasts.

The cells were seeded in 60-mm culture dish and treated with the indicated doses of the oil extracts and $\beta$-carotene for $24 \mathrm{~h}$. The expression levels of collagens and MMPs were analyzed using by qRT-PCR experiments. (A) The oil extracts increased COL1A1 mRNA expression in dermal fibroblasts. (B) Dose-dependent decreases on MMP1 and MMP3 mRNA expressions in the oil-treated dermal fibroblasts. (C) The $\beta$-carotene increased COL1A1 and COL3A1 mRNA expressions in dermal fibroblasts. (D) Dose-dependent decreases on MMP1 and MMP3 mRNA expressions in $\beta$-carotene-treated dermal fibroblasts. Adenosine was used as the positive control. Each bar shows mean \pm S.D. from three independent experiments. ${ }^{*} p<0.05$ compared with control.

을 이용하여 분석하였다. 분석결과, $10 \mathrm{~J} / \mathrm{cm}^{2} \mathrm{UVA}$ 조사는 세포 내 $C O L 1 A 1$ 및 COL3A1 mRNA의 발현을 $29.66 \pm 5.17 \%$ 및 $23.69 \pm$ $5.24 \%$ 감소시켰으나, 5 및 $10 \mu \mathrm{M}$ 의 $\beta$-carotene 처리시 COL1A1 $\mathrm{mRNA}$ 의 발현이 $20.59 \pm 4.86 \%$ 및 $10.48 \pm 3.56 \%$ 감소됨이 나타 났으며, COL3A1 mRNA의 발현은 $13.59 \pm 4.15 \%$ 및 $13.014 \pm$ $11.63 \%$ 감소됨이 나타났다(Figure 5). 따라서, 본 연구결과를 통 해 $\beta$-carotene은 자외선에 의한 피부세포 내 콜라겐 발현량 감소 을 억제하는 효능이 존재함을 밝혔다.

피부의 자외선에 대한 보호는 피부 노화 및 흑색종(melanoma) 와 같은 피부 질환을 방지하는데 중요하다(Ganceviciene et al., 2012) 따라서, 자외선의 피부 손상 기전과 자외선의 피부 노출 억 제에 관하여 알고자 하는 요구가 증가되고 있다. 가장 대표적인 피 부 노화의 현상은 자외선으로 인한 피부 세포의 성장력 감소 및 이 로 인한 콜라겐 발현 감소와 MMPs 발현 증가에 따른 콜라겐 분 해 증가이다(Sjerobabski-Masnec et al., 2010). 기존 연구에 따 르면, 미세조류로부터 분리한 추출물 또는 단일 화합물이 피부 주
름 억제와 선크림의 성분으로써 효과적일 수 있음을 증명하였다 (Grether-Beck et al., 2008; Regnier et al., 2015). 따라서, 본 연구논문에서도 미세조류 중 하나인 Chlorella sp. HS1 오일 추출 물이 자외선에 의한 세포 손상을 조절 할 수 있는지를 분석하였으 며, 이를 통해 항 자외선제(anti-UV reagent)로서의 가능성을 보 여주었다. 본 연구결과를 통해 Chlorella $s p$. HS1 유래 오일 추출 물은 낮은 세포독성과 자외선에 의한 진피섬유아세포 내 콜라겐 발 현 감소를 억제하는 효과를 증명하였다.

최근 연구결과에 따르면 자외선에 의한 피부 흑색종의 발병은 $\mathrm{SFP} 50$ 자외선 차단제를 피부에 도포함으로써 지연시킬 수 있으나, 해당 보호 효과는 $100 \%$ 로 나타나지 않으며, 이는 일부 자외선이 선크림을 통과해 피부에 영향을 미칠 수 있다는 것을 제시하였다 (Viros et al., 2014). 또한, 비규칙적인 자외선 차단제 도포 및 단 회성의 자외선 차단제 도포는 인간 피부에 자외선에 의한 DNA 손 상도 현저히 증가됨을 보였다(Al et al., 2002). 이러한 기존 연구 논문들은 자외선 차단제를 통한 물리적 보호(physical protection) 


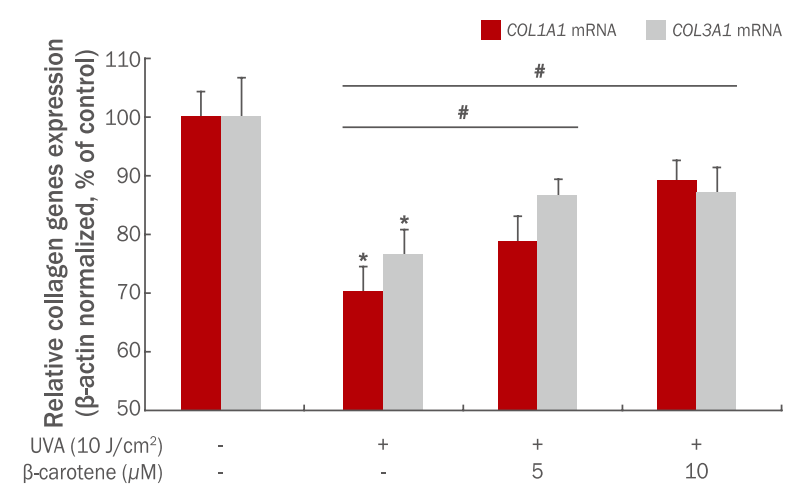

Figure 5. Effect of $\beta$-carotene on the expression of COL1A1 and COL3A1 mRNAs in UVA-irradiated human dermal fibroblasts. The cells were seeded and pretreated with the indicated doses of $\beta$-carotene for $6 \mathrm{~h}$. After UVA $\left(10 \mathrm{~J} / \mathrm{cm}^{2}\right)$ irradiation, the cells were post-treated with $\beta$-carotene, and the expression levels of collagens were analyzed using by qRT-PCR experiments. The results are presented as the mean \pm S.D. of three independent experiments. ${ }^{*}, \#<0.05$ compared with DMSO-treated and UVAirradiated control cells as determined by $t$-test.

는 자외선에 의한 세포 손상 및 노화에 제한적일 수 있다는 것을 제 시한다. 본 연구논문에서는 Chlorella sp. HS1 유래 오일 추출물은 자외선에 의한 콜라겐 발현 감소 및 MMPs 발현 증가를 현저하게 억제하였으며, 해당 효과가 베타카로틴에 의해서 나타남을 제시해, Chlorella sp. HS1 유래 오일 추출물이 자외선에 의한 피부 노화를 저해하는 잠재적인 중요성을 가진다는 것을 밝혔다.

Chlorella sp. 유래 물질 기반 피부 보호 효능에 대해서 여러 연 구논문들이 발표되었다. 베타클루칸( $\beta$-glucan)은 Chlorella $s p$. 내 존재하는 다당류 중 하나로, 항산화 효력에 대한 우수성이 발표되 어, 자외선에 의한 피부 세포 내 활성산소 증가 및 이를 통한 노화 유발에 대한 보호 효능이 제시되었다(Hamed et al., 2016). 또한 Chlorella vulgaris 추출물이 항산화 효과를 통해 콜라겐 수복 기 전을 돕는 역할에 대해서도 보고되었다(Chandra et al., 2017). 뿐 만 아니라, Chlorella vulgaris 추출물은 피부의 콜라겐 생합성을 증가시키며, 이를 통해 주름 개선에 대한 잠재적 효능이 제시되었 다(Spolaore et al., 2006). 종합하자면, Chlorella sp. 추출물의 항 산화 효력 및 콜라겐 합성 증가력에 대해서는 보고되었지만, 자외 선에 의한 피부세포 내 콜라겐 발현 조절 및 관련 유효성분에 대해 서는 아직까지 보고되지 않았다. 본 연구논문은 Chlorella $s p$. HS1 유래 오일 추출물이 자외선이 조사된 인간 진피섬유아세포 내 콜라 겐 감소를 회복시키는 데 효과가 있음을 밝혔으며, 동시에 콜라겐 분해효소 MMPs 발현 증가에 대한 억제 효력도 존재함을 증명하였 다. 또한, 이러한 효과는 Chlorella sp. HS1 유래 오일 추출물 내 지표성분인 베타카로틴에 의해서 나타남을 보였다. 따라서, 본 연 구결과를 통해Chlorella sp. HS1 유래 오일 추출물이 신규 자외선 에 의한 피부 노화 방지 효력에 관한 잠재적인 물질임을 제시해, 관
련 항노화 화장품 개발에 중요한 영향을 미칠 것으로 사료된다.

\section{Conclusion}

결론적으로 본 논문에서 Chlorella sp. HS1의 오일 추출물은 진 피섬유아세포 내 콜라겐 유전자 발현량을 증가시키고, 또한 자외선 에 의해 유도된 콜라겐 발현 저하도 억제하는 효능이 존재함을 밝 혔다. 또한 유의적으로 콜라게나제 발현을 감소하는 효능이 존재함 을 밝혔다. 특히, HPLC를 통해 $\beta$-carotene이 주요한 구성성분임 을 밝혔으며, 오일추출물보다 높은 세포 내 콜라겐 발현 증가 및 콜 라게나제 발현 억제 효과가 관찰되었다. 따라서 본 연구결과를 통 해 Chlorella sp. HS1의 오일 추출물은 피부 주름개선을 유도하는 억제할 수 있는 신규 화장품 물질로서 사용될 수 있는 가능성을 보 여주었다. 추가적인 연구를 통해 Chlorella $s p$. HS1의 오일 추출물 을 통한 차후 광노화 억제 효과 및 관련 기전 규명은 학술적인 가치 가 높다고 사료된다.

\section{Acknowledgements}

본 논문은 2019년 해양수산부 재원으로 해양수산과학기술진흥 원의 지원을 받아 수행된 연구임(과제번호: 20190070).

\section{Author's contribution}

HBK and JYK performed biochemical and cellular experiments. YJL performed the preparation of the microalgae cultivation and experiments of extraction. SA, DYC and HSK assisted with experimental design and analyzed data. SB designed this project and wrote the manuscript with assistance from SA.

\section{Author details}

Hye-Bin Kim (Graduate student/Ph.D. candidate), Department of Cosmetics Engineering, Konkuk University, 120 Neungdong-ro, Gwangjin-gu, Seoul 05029, Korea; Ji Yea Kim (Post-Doc. Researcher), Department of Cosmetics Engineering, Konkuk University, 120 Neungdongro, Gwangjin-gu, Seoul 05029, Korea; Sungkwan An (Professor), Department of Cosmetics Engineering, Konkuk University, 120 Neungdong-ro, Gwangjin-gu, Seoul 05029, Korea; Yong Jae Lee (Associate Researcher), Sustainable Bioresource Research Center, KRIBB, 125 Gwahak-ro, Yuseong-gu, Daejeon 34141, Korea; DaeHyun Cho (Researcher), Sustainable Bioresource Research Center, KRIBB, 125 Gwahak-ro, Yuseong-gu, Daejeon 
34141, Korea; Hee-Sik Kim (Principle Researcher), Sustainable Bioresource Research Center, KRIBB, 125 Gwahak-ro, Yuseong-gu, Daejeon 34141, Korea; HeeSik Kim (Professor), Green Chemistry and Environmental Biotechnology, University of Science and Technology (UST), 217 Gajeong-ro, Yuseong-gu, Daejeon 34113, Korea; Seunghee Bae (Assistant Professor), Department of Cosmetics Engineering, Konkuk University, 120 Neungdong-ro, Gwangjin-gu, Seoul 05029, Korea.

\section{References}

Al Mahroos M, Yaar M, Phillips TJ, Bhawan J, Gilchrest BA. Effect of sunscreen applcation on UV-induced thymine dimers. Archive Dermatology, 138: 1480-1485, 2002.

Blanpain C, Fuchs E. Epidermal stem cells of the skin. Annual Review of Cell and Developmental Biology, 22: 339-373, 2006.

Brennan M, Bhatti H, Nerusu KC, Bhagavathula N, Kang S, Fisher GJ, Varani J, Voorhees JJ. Matrix metalloproteinase-1 is the major collagenolytic enzyme responsible for collagen damage in UV-irradiated human skin. Photochemistry and Photobiology, 78: 43-48, 2003.

Chandra R, Parra R, lqbal HMN. Phycobiliproteins: a novel green tool from marine origin blue-green algae and red algae. Protein Peptide Letters, 24: 118-125, 2017.

Fisher GJ, Wang ZQ, Datta SC, Varani J, Kang S, Voorhees JJ. Pathophysiology of premature skin aging induced by ultraviolet light. The New England Journal of Medicine, 337: 1419-1428, 1997.

Fisher GJ, Varani J, Voorhees JJ. Looking older: fibroblast collapse and therapeutic implications. Archive of Dermatology, 144: 666-672, 2008.

Ganceviciene R, Liakou Al, Theodoridis A, Makrantonaki E, Zouboulis CC. Skin anti-aging strategies. Dermatoendocrinology, 4: 308-319, 2012.

Grether-Beck S, Mühlberg K, Brenden H, Felsner I, Brynjólfśóttir A, Einarsson S, Krutmann J. Bioactive molecules from the blue Lagoon: in vitro and in vivo assessment of silica mud and microalgae extracts for their effects on skin barrier function and prevention of skin ageing. Experimental Dermatology, 17: 771-779,
2008.

Hamed, I. The evolution and versatility of microalgal biotechnology: a review. Comprehensive Reviews in Food Science and Food Safety, 15: 1104-1123, 2016.

Hasegawa T, Noda K, Kumamoto S, Ando Y, Yamada A, Yoshikai Y. Chlorella vulgaris culture supernatant (CVS) reduces psychological stress-induced apoptosis in thymocytes of mice. International Journal of. Immunopharmacology, 22: 877-885, 2000.

Jiang $\mathrm{H}$, Chen W, Qu L, Chen Y, He Q, Wang H, Wu J, Shou Z, Ju Z, Chen J. ELISA for aging biomarkers induced by telomere dysfunction in human plasma. Journal of Biomedicine and Biotechnology, 2010: 121947, 2010.

Kazanci A, Kurus M, Atasever A. Analyses of changes on skin by aging. Skin Research Technology, 23: 48-60, 2016.

Kitada K, Machmudah S, Sasaki M, Goto M, Nakashima $\mathrm{Y}$, Kumamoto S, Hasegawa T. Supercritical $\mathrm{CO}_{2}$ extraction of pigment components with pharmaceutical importance from Chlorella vulgaris. Journal of Chemical Technology and Biotechnology, 84: 657-661, 2009.

Kim KB, Lee JJ, Heo JA, Cho DH, Kim HS, Kim KN, Kim SY, Ahn $\mathrm{KJ}, \mathrm{An}$ IS, An S, Bae S. The extract of Chlorella vulgaris exerts protective effects against ultraviolet $B$ radiationinduced damages in human dermal fibroblasts. Asian Journal of Beauty and Cosmetology, 12: 479-486, 2014.

Krienitz L, Huss VA, Bock C. Chlorella: 125 years of the green survivalist. Trends in Plant Sciences, 20: 67-69, 2015.

Krutmann J, Bouloc A, Sore G, Bernard BA, Passeron T. The skin aging exposome. Journal of Dermatological, 85: 152-161, 2017.

Lee HS, Park HJ, Kim MK. Effect of Chlorella vulgaris on lipid metabolism in wistar rats fed high fat diet. Nutrition Research Practice, 2: 204-210, 2008.

Makpol S, Yaacob N, Zainuddin A, Yusof YAM, Ngah WZW. Chlorella vulgaris modulates hydrogen peroxide-induced DNA damage and telomere shortening of human fibroblasts derived from different aged individuals. African Journal of Traditional, Complementary and Alternative Medicine, 6:560-572, 2009.

Mora Huertas AC, Schmelzer CE, Hoehenwarter W, Heyroth F, Heinz A. Molecular-level insights into aging processes of skin elastin. Biochimie, 128-129:163-173, 2016.

Panahi Y, Pishgoo B, Jalalian HR, Mohammadi E, Taghipour 
HR, Sahebkar A, Abolhasani E. Investigation of the effects of Chlorella vulgaris as an adjunctive therapy for dyslipidemia: results of a randomized open-label clinical trial. Nutrition and Dietetics, 69: 13-19, 2012.

Pittayapruek P, Meephansan J, Prapapan O, Komine $\mathrm{M}$, Ohtsuki M. Role of matrix metalloproteinases in photoaging and photocarcinogenesis. International Journal of Molecular Sciences, 17: 868, 2016.

Quan T, Little E, Quan H, Qin Z, Voorhees JJ, Fisher GJ. Elevated matrix metalloproteinases and collagen fragmentation in photodamaged human skin: impact of altered extracellular matrix microenvironment on dermal fibroblast function. Journal of Investigative Dermatology, 133: 1362-1366, 2013.

Quan T, Fisher GJ. Role of age-associated alterations of the dermal extracellular matrix microenvironment in human skin aging. Gerontology, 61: 427-434, 2015.

Regnier P, Bastias J, Rodriguez-Ruiz V, Caballero-Casero N, Caballo C, Sicilia D, Fuentes A, Maire M, Crepin M, Letourneur D, et al. Astaxanthin from Haematococcus pluvialis prevents oxidative stress on human endothelial cells without toxicity. Marine Drugs, 13: 2857-2874, 2015.

Sjerobabski-Masnec I, Situm M. Skin aging. Acta Clinica Croatica, 49: 515-518, 2010.

Spolaore P, Joannis-Cassan C, Duran E, Isambert A. Commercial applications of microalgae. Journal of Bioscience and Bioengineering, 101: 87-96, 2006.

Viros A, Sanchez-Laorden B, Pedersen M, Furney SJ, Rae J, Hogan K, Ejiama S, Glrotti MR, Cook M, Dhomen N, Marais R. Ultraviolet radiation accelerates BRAF-driven melanomagenesis by targeting TP53. Nature, 511: 478-482, 2014.
Sulaiman S, Shamaan NA, Ngah WZW, Yusof YAM. Chemopreventive effect of Chlorella vulgaris in choline deficient diet and ethionine induced liver carcinogenesis in rats. International Journal of Cancer Research, 2: 234-241, 2006.

Varani J, Warner RL, Gharaee-Kermani M, Phan SH, Kang S, Chung JH, Wang ZQ, Datta SC, Fisher GJ, Voorhees JJ. Vitamin a antagonizes decreased cell growth and elevated collagen-degrading matrix metalloproteinases and stimulates collagen accumulation in naturally aged human skin. Journal of Investigative Dermatology, 114: 480-486, 2000.

Vecina JF, Oliveira AG, Araujo TG, Baggio SR, Torello CO, Saad MJ, Queiroz ML. Chlorella modulates insulin signaling pathway and prevents high-fat diet-induced insulin resistance in mice. Life Sciences, 95: 45-52, 2014.

Wang HM, Pan JL, Chen CY, Chiu CC, Yang MH, Chang HW, Chang JS. Identification of anti-lung cancer extract from Chlorella vulgaris C-C by antioxidant property using supercritical carbon dioxide extraction. Process Biochemistry, 45: 1865-1872, 2010.

Yasui T, Yonetsu M, Tanaka R, Tanaka Y, Fukushima S, Yamashita T, Ogura Y, Hirao T, Murota H, Araki T. In vivo observation of age-related structural changes of dermal collagen in human facial skin using collagen-sensitive second harmonic generation microscope equipped with 1250-nm mode-locked Cr: forsterite laser. Journal of Biomedical Optics, 18: 31108, 2013.

Zhang S, Duan E. Fighting against skin aging: the way from bench to bedside. Cell Transplantation, 27: 729-738, 2018. 


\section{국문초록}

\section{인간 진피섬유아세포에서 Chlorella sp. HS1 유래 오일의 콜라겐 발현 증가 효력에}

\section{관한 연구}

김혜빈 ${ }^{1}$, 김지예 ${ }^{1}$, 안성관 $^{1}$, 이용재 ${ }^{2}$, 조대현 ${ }^{2}$, 김희식 ${ }^{2,3}$, 배승희 ${ }^{1 *}$

${ }^{1}$ 건국대학교 화장품공학과 질병분자표적신약연구소, 서울, 한국

${ }^{2}$ 한국생명공학연구원 세포공장연구센터, 대전, 한국

${ }^{3}$ 과학기술연합대학원대학교 환경바이오공학전공, 대전, 한국

목적: 본 연구는 Chlorella sp. HS1 유래 오일의 진피섬유아세포 내에서 콜라겐 발현에 관한 효과를 분석하고자 하였다. 방법: Chlorella sp. HS1 바이오매스로부터 오일을 추출한 후, 고성능액체크로마토그래피 분석을 통해 추출물 내의 성분 종류와 함량을 분석하였다. 인간 진피섬유아세포를 대상으로, 오일 추출물 처리에 따른 세포 생존율과 정량적 RT-PCR분석을 통한 콜라겐과 콜 라겐분해효소 발현량을 분석하였다. 뿐만 아니라, 오일 추출물에 의한 콜라겐 발현 효과가 지표 성분인 베타카로틴에 의한 것인지 에 대하여도 분석하였다. 또한, 자외선이 조사된 진피섬유아세포의 보호효능에 대한 베타카로틴의 효과에 대해서도 분석하였다. 결 과: 오일 추출물 $50 \mu \mathrm{g} / \mathrm{mL}$ 이하의 농도에서 각질형성세포, 멜라닌형성세포, 진피섬유아세포의 세포 생존율에는 영향이 낮음을 보 였다. 고성능액체크로마토그래피 분석을 통해, 오일 추출물 내 베타카로틴이 가장 주요한 성분으로 나타났으며, 베타카로틴을 진피 섬유아세포 처리시 낮은 세포독성을 나타냈다. 추가적인 실험을 통해 오일 추출물 처리시 콜라겐 타입 1 과 타입 3 의 발현이 현저하 게 증가하였으며, $M M P 1$ 과 $M M P 3$ 의 발현은 현저하게 감소되었다. 이러한 효과는 베타카로틴을 처리한 세포에서도 동일하게 나타 났다. 또한, 베타카로틴은 자외선에 의해 유도되는 콜라겐 타입 1 과 타입 3 의 발현 감소를 현저하게 회복시키는 효과가 나타났다. 결론: 본 연구결과를 통해 베타카로틴이 함유된 Chlorella sp. HS1 유래 오일의 주름개선 성분의 가능성을 제시하였다.

핵심어: Chlorella sp., 진피섬유아세포, 항노화, 콜라겐, 베타카로틴

본 논문은 2019년 해양수산부 재원으로 해양수산과학기술진흥원의 지원을 받아 수행된 연구임(과제번호: 20190070).

\section{참고문헌}

김기쁨, 이정주, 허진아, 조대현, 김희식, 김광년, 김수영, 안규중, 안인숙, 안성관, 배승희. Chlorella vulgaris 미세조 류 추출물의 자외선B 의존적 인간 진피섬유아세포 손상에 대한 보호 효능 연구. 아시안뷰티화장품학술지, 12: 479486, 2014. 


\section{中文摘要}

\section{Chlorella sp. HS1油对人真皮成纤维细胞的抗皱作用}

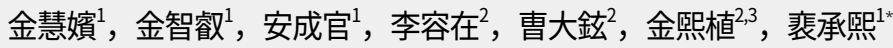

建国大学生物工学科化妆品学科疾病分子靶标新药研究所, 首尔, 韩国

2韩国生命工学研究院细胞工厂研究中心, 大田, 韩国

3科学技术联合大学院大学环境生物工学科, 大田, 韩国

目的: 研究Chlorella sp. HS1油对真皮成纤维细胞胶原表达的影响。方法: 采用高效液相色谱法对小球藻HS1生 物量油提物进行成分鉴定和含量测定。利用人真皮成纤维细胞, 细胞活力和定量RT-PCR (qRT-PCR) 介导的油 处理后胶原和基质金属蛋白酶 (MMP) 基因表达分析。我们进一步研究了Chlorella sp. HS1油提取物对胶原表 达的影响是否与提取物的主要成分 $\beta$-胡夢卜素有关。此外, 我们还分析了 $\beta$-胡夢卜素对紫外线照射真皮成纤维 细胞的光保护作用。结果: $50 \mu \mathrm{g} / \mathrm{mL}$ 以下的油提取物对表皮角质形成细胞、黑素细胞、真皮成纤维细胞等皮肤 细胞的毒性较小。HPLC分析表明 $\beta$-胡夢卜素是主要的非极性分子。其次, 我们发现油源性 $\beta$-胡夢卜素对真皮成 纤维细胞的细胞毒性很小。进一步的实验表明, Chlorella sp. HS1油提取物对真皮成纤维细胞的1型和3型胶原 mRNAs有显著的上调作用, 对 MMP1和MMP3 mRNAs有显著的下调作用。同时, 我们发现这些效应在 $\beta$-胡萝卜 素处理的细胞中也有表现。此外, $\beta$-胡夢卜素显著减弱UVA诱导的1型和3型胶原表达下调。结论: 本实验结果表 明, 该油提取物主要成分 $\beta$-胡夢卜素具有潜在的抗皱作用。

关键词: 小球藻, 真皮成纤维细胞, 抗衰老, 胶原蛋白, $\beta$-胡夢卜素 
